\title{
Botanical Composition, Grass Production, and Carrying Capacity of Pasture in Timor Tengah Selatan District
}

\author{
V. E. Se' $\mathbf{u}^{\mathrm{a}}$, P. D. M. H. Kartib, ${ }^{\mathrm{b}}$, \& L. Abdullah ${ }^{\mathrm{b}}$ \\ aStudy Program of Nutrition and Feed Science, Faculty of Animal Science, Graduate School, \\ Bogor Agricultural University \\ ${ }^{b}$ Department of Nutrition and Feed Technology, Faculty of Animal Science, Bogor Agricultural University \\ Jalan Agatis, Kampus IPB Darmaga Bogor 16680, Indonesia \\ (Received 28-05-2015; Reviewed 29-06-2015; Accepted 24-08-2015)
}

\begin{abstract}
This study was conducted to analyze the botanical composition, grass production, carrying capacity, and potential production of nutrients in pasture located in Timor Tengah Selatan Regency. The experiment was conducted from February to July 2013, using field survey method. The botanical composition, grass production and carrying capacity on real condition were analyzed descriptively, while the grass production and carrying capacity based of cutting arrangement were analyzed by using randomized block factorial design with 3 altitude locations (Sub District of Mollo Utara with altitude of $1007 \mathrm{~m}$ above sea level; Sub District of Noebeba, $500 \mathrm{~m}$ ASL, and Sub District of Amanuban Selatan, 65 m ASL) $x 2$ cutting intervals ( 1 and 2 month) and 5 replications. The results showed that the grass type dominated the pasture in the Sub District of Mollo Utara, while legum type was more dominant in the pasture in the Sub Districts of Noebeba and Amanuban Selatan. The potential production of dry matter grass in Timor Tengah Selatan Regency based on real condition was 150 to $390 \mathrm{~kg} / \mathrm{ha} / \mathrm{yr}$, this could accommodate 0.24 to $0.63 \mathrm{AU} / \mathrm{ha} / \mathrm{yr}$. The arrangement of cutting interval by 1 month in Mollo Utara and 2 months in Noebeba and Amanuban Selatan could increase $(P<0.05)$ grass production and carrying capacity. The potential productions of grass nutrients were higher in Sub District of Mollo Utara, while potential production of grass dry matter was higher in Sub Districts of Noebeba and Amanuban Selatan. It was concluded that grass dry matter potential production and carrying capacity in Timor Tengah Selatan Regency were low. The arrangement of cutting interval could increase grass dry matter potential production, carrying capacity, nutrition production, and quality of nutrition.
\end{abstract}

Key words: carrying capacity, grass, pasture, Timor Tengah Selatan

\section{ABSTRAK}

Penelitian ini bertujuan untuk menganalisis komposisi botani, produksi rumput, kapasitas tampung dan produksi nutrisi rumput pada padang penggembalaan di Kabupaten Timor Tengah Selatan. Penelitian dilaksanakan bulan Februari sampai Juli 2013, menggunakan metode survei lapang. Variabel komposisi botani, potensi produksi bahan kering rumput, dan kapasitas tampung pada kondisi riil, serta potensi produksi nutrisi rumput dianalisis secara deskriptif, sedangkan produksi rumput dan kapasitas tampung berdasarkan pengaturan pemotongan dianalisis menggunakan rancangan acak kelompok pola faktorial, yaitu 3 lokasi dengan ketinggian berbeda $x 2$ interval pemotongan dengan 5 ulangan. Hasil menunjukkan bahwa rumput mendominasi padang penggembalaan di Kecamatan Mollo Utara, sedangkan leguminosa mendominasi padang penggembalaan di Kecamatan Noebeba dan Amanuban Selatan. Produksi rumput pada kondisi riil di Kabupaten Timor Tengah Selatan sebanyak 150-390 kg/ha/thn dapat menampung 0,24-0,63 ST/ha/thn. Pengaturan pemotongan dengan interval pemotongan 1 bulan di Kecamatan Mollo Utara, 2 bulan di Kecamatan Noebeba dan Amanuban Selatan dapat meningkatkan $(\mathrm{P}<0,05)$ produksi rumput dan kapasitas tampung. Potensi produksi nutrisi rumput tertinggi terdapat di Kecamatan Mollo Utara, sedangkan potensi produksi bahan kering rumput tertinggi di Kecamatan Noebeba dan Amanuban Selatan. Disimpulkan bahwa produksi rumput dan kapasitas tampung di Timur tengah Selatan adalah rendah. Kondisi pengaturan pemotongan dapat meningkatkan produksi, kapasitas tampung, dan kualitas nutrisi rumput.

Kata kunci: kapasitas tampung, rumput, padang penggembalaan, Timor Tengah Selatan

*Corresponding author:

E-mail: pancadewi fapetipb@yahoo.com 


\section{INTRODUCTION}

The activities of cattle, horses and goats farming have been widely applied by the community that are scattered in several regions in Indonesian, especially communities in Timor Tengah Selatan District, East Nusa Tenggara Province. Timor Tengah Selatan District is one of the districts in East Nusa Tenggara Province that has many populations of Bali cattle, horse, and goat. The populations of Bali cattle, horse, and goat in East Nusa Tenggara Province were 185,021, 698, and 42,610 heads, respectively, with 832,288 ha pasture area (BPS, 2014). The district has population growth of Bali cattle by $4.0 \%-5.6 \%$.

Timor Tengah Selatan has tropic climate and generally changes every year. The dry season (seven months) is longer than rainy season (five months). Geographical location of Timor Tengah Selatan District is closer to Australia continent than to Asia leading to a lower rainfall. The number of rainy days is high in December and the highest rainfall is occurred in January, while the lowest rainfall is occurred in September. Timor Tengah Selatan District has rainfall of 1,532.15 mm with rainy days as much as $91 \mathrm{~d}$ (BPS, 2014). Timor Tengah Selatan District consists of some areas with different topographies including the Sub Districts of Mollo Utara, Noebeba, and Amanuban Selatan. Sub district of Mollo Utara is in the Mutis Mountains, Sub District of Noebeba area is on the outskirts of the Oebaki and Noesaha Rivers, while Sub District of Amanuban Selatan is near the Oetune beach. Those three subdistricts have wide area of pastures, therefore the cattle population in this region can be increased easily. This potential is related to the availability of land for forage production and carrying capacity of pastures.

An extensive system in pasture is applied during a day, while an intensive system is applied at night (Manu, 2013). According to Salendu \& Elly (2012), the forage fed to cattle is domestic forage. Domestic forage in Timor is natural grass that is grown around the houses, garden, or deliberately cultivated such as king grass. Forage types that are mostly eaten by the ruminant animals are grass family (Gramineae) and legume (Leguminoceae). The problem of domestic forage is its low productivity and nutrient content and limited development (Salendu \& Elly, 2012), whereas the optimization of forage potential is important for continuous supply of the forage (Tola et al., 2007). For this purpose, this study was conducted to analyze the botanical composition, grass dry matter production potential, carrying capacity as well as the nutrition production and quality of nutrition in the supplying of domestic forage in Timor Tengah Selatan to support the sustainability development of ruminant livestock.

\section{MATERIALS AND METHODS}

This research was conducted in February to July 2013 in the Sub Districts of Mollo Utara, Noebeba and Amanuban Selatan in Timor Tengah Selatan District. The location of the research was determined purposively (purposive sampling). This area has different altitudes and topographies but the vegetation is homogenous and has the potential to supply domestic forage for animal feed.

Sampling method used in the study was Cluster Random Sampling by using the equation (Som, 1996): $\mathrm{n}=\mathrm{N} /\left(1+\mathrm{Ne}^{2}\right)$

where: $\mathrm{N}=$ total farmers, $\mathrm{e}=$ error $(10 \%), \mathrm{n}=$ total sample.

Numbers of respondents were 94 farmer families from nine villages in three sub-districts from whom the information regarding farmer, number of cattle, and forage supply patterns were obtained by using questionnaires.

\section{Data Collection}

Data collection consisted of primary and secondary data. Primary data were obtained from the field observations and interviews. The field observation was conducted in pasture, while the interviews were conducted by using a questionnaire for 94 respondents from Sub Districts of Mollo Utara, Noebeba, and Amanuban Selatan. Secondary data were literature data from Livestock Agencies and Central Bureau of Statistics of Timor Tengah Selatan District.

Production of herbarium and forage identification. Production of forage herbarium used Stone method (Stone, 1983). Forage identification (Quattrocchi, 2006) was used to identify the physical characteristics and compare them with relevant literature to find the scientific name of forage.

\section{Data Analysis}

Botanical composition analysis. Botanical composition analysis was conducted on pasture by observing the species in each plots with size $1 \times 1 \mathrm{~m}^{2}$ as many as 10 plots in each location. The forage species contained in the plots was observed and recorded which consisted of three ranks. All ranks were not fully filled, so that the number of ranks was different, therefore each rank was multiplied by $8.04: 2.41: 1.0$ constant to calculate the percentage of botanical composition of each species (Mannetje \& Haydock, 1963).

Potential production of grass dry matter and carrying capacity analysis based on real conditions. The frame was thrown 30 times per pasture. The forages in the frame were cut as high as $5 \mathrm{~cm}$ from the land surface and weighed. The procedures to count forage production (ton $/ \mathrm{m}^{2}$ ) and carrying capacity used the method of Halls et al. (1964):

1. Weighing of grass dry matter production of $1 \mathrm{~m}^{2}$ area.

2. Proper Use Factor (PUF 70\%) based on the level of grazing and soil erosion rates.

3. Calculation of the grass dry matter production available $\left(\mathrm{kg} / \mathrm{m}^{2}\right)=$ grass dry matter production of $1 \mathrm{~m}^{2} \mathrm{x}$ PUF (70\%).

4. Tropical grassland takes $70 \mathrm{~d}$ to break (r) after graz- 
ing during the $30 \mathrm{~d}(\mathrm{~s})$. Voisin constants approach of using formula $(y-1) s)=r=3.3$, meaning in 1 ha of land can accommodate 3.3 heads of mature cattle consuming $40 \mathrm{~kg} / \mathrm{d}$ at the level of heavy grazing.

5. Calculation of the livestock consumption needs $(\mathrm{kg} /$ $\mathrm{AU})=(6.29 \mathrm{~kg} \times 30 \mathrm{~d}) / 1000$.

6. Calculation of the land area needs per month (ha/ $\mathrm{AU})=$ consumption needs / grass dry matter production available.

7. Calculation of the land area needs per year (ha/AU/ $\mathrm{yr})=$ land area needs per month $\mathrm{x}$ Voisin constant.

8. Calculation of the carrying capacity $(\mathrm{AU} / \mathrm{ha} / \mathrm{yr})=$ Standard unit of mature cattle / land area needs per year.

Potential production of grass dry matter and carrying capacity analysis based on cutting arrangement. Observations were carried out on pasture by making 10 plots with a size of $1 \times 1 \mathrm{~m}^{2}$ in each sub district and fenced to prevent livestock from grazing. Furthermore cutting all types of grass as high as $5 \mathrm{~cm}$ above ground level and weighing grass that was in the plot. Calculation was conducted on the grass dry matter production potential and carrying capacity based on cutting interval by Halls et al. (1964):

1. Weighing of grass dry matter production of $1 \mathrm{~m}^{2}$ area.

2. Proper Use Factor (PUF 70\%) based on the level of grazing and soil erosion rates.

3. Calculation of grass dry matter production available in the dry season and the rainy season $(\mathrm{kg} / \mathrm{ha})=$ grass dry matter production of $1 \mathrm{~m}^{2}(\mathrm{~kg} / \mathrm{ha})$ x PUF $(70 \%) \times 1000$.

4. Calculation of requirement of livestock consumption $(\mathrm{kg} / \mathrm{AU})=6.29 \mathrm{~kg} \times$ number of days cutting interval.

5. Calculation of carrying capacities (AU/ha/yr)= Grass dry matter production available / livestock consumption needs

The experimental design used in the analysis of forage production potential and carrying capacity by the cutting arrangement was a $3 \times 2$ factorial randomized block design with 5 replications. The first factor was the altitude of the location, namely: Sub District of Mollo Utara with altitude of 1,007 $\mathrm{m}$ above sea level; Sub District of Noebeba with altitude of $500 \mathrm{~m}$ above sea level, and Sub District of Amanuban Selatan with altitude of $65 \mathrm{~m}$ above sea level. The second factor was the cutting interval, namely: 1 month and 2 month. The data were analyzed by analysis of variance ANOVA, and when a significant effect of treatment was found, Duncan's Multiple Range Test was used to determine the significant difference among means values (Steel \& Torrie, 1993).

Analysis of the grass nutrition production and quality of nutrition. The grass samples were taken from the three sub districts and analyzed by proximate analysis (AOAC, 2005) and Van Soest (Tillman et al., 1983). The results obtained were analyzed descriptively.

\section{RESULTS AND DISCUSSION}

\section{General Condition of the Research Area}

Timor Tengah Selatan District has an area of about $3,955.36 \mathrm{~km}^{2}$ and consists of $32 \mathrm{sub}$ districts and 228 villages. Approximately $90.83 \%$ of these sub districts are mountainous areas (BPS, 2014). Sub District of Mollo Utara is a region in the Mutis Mountains with altitude of $1,007 \mathrm{~m}$ above sea level. The average air temperature was $20-24^{\circ} \mathrm{C}$ with a rainfall of $2,713.4 \mathrm{~mm}$ and 129 days of rain. Sub District of Noebeba is near the Oebaki and Noesaha Rivers with a height of $500 \mathrm{~m}$ above sea level, the average air temperature is $31-34^{\circ} \mathrm{C}$ with a rainfall of $665 \mathrm{~mm}$ and 55 days of rain, while Amanuban Selatan Sub Distric is near the Oetune beach with a height of $65 \mathrm{~m}$ above sea level. The average air temperature is $34-39^{\circ} \mathrm{C}$ with a rainfall of $665 \mathrm{~mm}$ and 55 days of rain. Based on the data obtained, the education of the respondents was very diverse namely, elementary, junior high, and high school. Most of the respondents work as farmers $(98.9 \%)$. The average income of the respondents was 500,000 rupiahs per month and it depends on the sale of agriculture or livestock products.

Timor Tengah Selatan District had the highest population of Bali cattle $(61.7 \%)$ compared with horses and goats. Cattle identification used ear tag and special stamp on the thigh. Sub Districts of Mollo Utara, Noebeba, and Amanuban Selatan has a wide pasture area. The populations of livestock in the Sub Districts of Mollo Utara, Noebeba, and Amanuban Selatan are presented in Table 1.

Extensive system in pastures was applied during the day, while intensive system was applied at night. Cattle houses were not far from home and close to farm land, so that the animals can utilize the agricultural products. Farmers utilized domestic grass that grew around the fields and gardens as animal feed. The type of feed utilization in the region was very different as influenced by the level of feed availability (Rusdin et al., 2009).

\section{Botanical Composition}

The botanical composition of forage in Timor Tengah Selatan District is presented in Table 2. The percentage of botanical composition in the Sub District of Mollo Utara consisted of $73.27 \pm 10.25 \%$ of grass and $7.10 \pm 3.71 \%$ of legumes; in the Sub District of Noebeba consisted of $64.51 \pm 6.08 \%$ of grass and $20.23 \pm 4.28 \%$ of legumes, and in the Sub District of Amanuban Selatan consisted of $63.98 \pm 6.33 \%$ grass and $23.46 \pm 2.77 \%$ legumes. Grass species was more dominant than other types of legume in the pastures (Hall \& Walker, 2005; Angassa et al., 2006). The more dominant grass species was due to the fast growth of grass to be clumps, strong root system that resistant to stamping of cattle, and the fast growth of grass after cutting inhibited the growth of legumes. The botanical composition of the pasture was not constant; it was influenced by climate, soil conditions, and grazing systems (Nunez et al., 2007). 
Table 1. The populations of livestock in the Sub Districts of Mollo Utara, Noebeba, and Amanuban Selatan (head)

\begin{tabular}{|c|c|c|c|c|c|c|}
\hline \multirow{3}{*}{ Type } & \multicolumn{6}{|c|}{ Populations of mature livestock } \\
\hline & \multicolumn{2}{|c|}{ Mollo Utara } & \multicolumn{2}{|c|}{ Noebeba } & \multicolumn{2}{|c|}{ Amanuban Selatan } \\
\hline & Mature $^{*}$ & Animal unit*) & Mature $\left.{ }^{*}\right)$ & Animal unit ${ }^{* *}$ & Mature*) & Animal unit*) \\
\hline Cattle & 10,658 & $10,658.00$ & 5,866 & $5,866.00$ & 14,659 & $14,659.00$ \\
\hline Horse & 78 & 78.00 & 0 & 0.00 & 11 & 11.00 \\
\hline Goat & 783 & 125.28 & 1,281 & 204.96 & 3,241 & 518.56 \\
\hline Total & 11,519 & $10,861.28$ & 7,147 & $6,070.96$ & 17,911 & $15,188.56$ \\
\hline
\end{tabular}

Note: ${ }^{*}$ BPS (2014), ${ }^{* *}$ Calculation of animal units= Population of livestock $x$ standard of mature animal unit (cattle and horse=1, goat= 0.16$)$.

Table 2. Botanical composition of forage in Timor Tengah Selatan District

\begin{tabular}{lccc}
\hline \multirow{2}{*}{ Location } & \multicolumn{3}{c}{ Botanical composition (\%) } \\
\cline { 2 - 4 } & Grass & Legume & Weeds \\
\hline $\begin{array}{l}\text { Mollo Utara } \\
(1,007 \text { m asl })\end{array}$ & $73.27 \pm 10.25$ & $7.10 \pm 3.71$ & $19.63 \pm 6.67$ \\
Noebeba (500 m asl) & $64.51 \pm 6.08$ & $20.23 \pm 4.28$ & $15.26 \pm 3.33$ \\
Amanuban Selatan & $63.98 \pm 6.33$ & $23.46 \pm 2.77$ & $12.56 \pm 2.73$ \\
$(65$ m asl) & & & \\
\hline
\end{tabular}

Note: asl= above sea level.

The quality of the pasture closely related to the botanical composition of the pasture (Junaidi \& Sawen, 2010).

\section{Potential Production of Grass Dry Matter and Carrying Capacity Analysis Based on Real Conditions}

Based on Table 3, Sub District of Noebeba had the highest availability of grass dry matter production (390 kg/ha). Determination of Proper Use Factor (PUF) value was based on the observations of wrench in each plot by observing the level of grazing, slope, type of soil, type of climate, and soil conditions. Based on the data obtained, the highest grass dry matter production was available in the Sub District of Noebeba as much as 390 $\mathrm{kg} / \mathrm{ha} / \mathrm{yr}$ that could accommodate as many as $0.63 \mathrm{AU} /$ ha/yr. Grass dry matter production available in the Sub District of Mollo Utara was $290 \mathrm{~kg} / \mathrm{ha} / \mathrm{yr}$ that could accommodate as many as $0.46 \mathrm{AU} / \mathrm{ha} / \mathrm{yr}$, while grass dry matter production available in the Sub District of Amanuban Selatan was very low i.e., $150 \mathrm{~kg} / \mathrm{ha} / \mathrm{yr}$ that was only able to accommodate as many as 0.24 cattle/ ha/yr. The number of cattle population in the three subdistricts (Table 1) was higher as compared to the grass dry matter production available (Table 3 ) resulting in an overgrazing. According to Susetyo (1980), the capacities of rangelands in Timor ranged from 0.70-4.60 AU/ha/ yr. The decrease in the quality and quantity of forage in Timor was due to the fewer number of rainy days, and the damage of the pasture caused by stamping of livestock (Jones \& Lefeuvre, 2006). In addition, the slope topography of the site caused nutrient leaching during rainy season (Njurumana et al., 2008).
Table 3. Grass dry matter production available and carrying capacity based on the real conditions

\begin{tabular}{lccc}
\hline \multirow{1}{*}{\multicolumn{1}{c}{ Components }} & \multicolumn{3}{c}{ Locations } \\
\cline { 2 - 4 } & $\begin{array}{c}\text { Mollo } \\
\text { Utara }\end{array}$ & Noebeba & $\begin{array}{c}\text { Amanuban } \\
\text { Selatan }\end{array}$ \\
\cline { 2 - 4 } & $(1007 \mathrm{~m}$ asl $)$ & $(500 \mathrm{~m}$ asl $)$ & $(65 \mathrm{~m}$ asl $)$ \\
\hline $\begin{array}{l}\text { Grass DM production } 1 \\
\mathrm{~m}^{2} \text { (kg/ha) }\end{array}$ & 420 & 560 & 220 \\
$\begin{array}{l}\text { Proper use factor/PUF (\%) } \\
\text { Grass DM production }\end{array}$ & 70 & 70 & 70 \\
$\begin{array}{l}\text { available (kg/ha/yr) } \\
\text { Livestock consumption } \\
\text { (kg/AU) }\end{array}$ & 290 & 390 & 150 \\
$\begin{array}{l}\text { Voisin constant (y-1) s }=\mathrm{r} \\
\text { Land area requirement } \\
\text { per month (ha/AU) }\end{array}$ & 190 & 190 & 190 \\
$\begin{array}{l}\text { Land area requirement } \\
\text { per year (ha/AU) }\end{array}$ & 0.65 & 3.3 & 3.3 \\
$\begin{array}{l}\text { Carrying capacity } \\
\text { (AU/ha/yr) }\end{array}$ & 2.14 & 1.58 & 1.26 \\
\hline
\end{tabular}

Note: DM= dry matter; asl= above sea level.

\section{Potential Production of Grass Dry Matter and Carrying Capacity Analysis Based on Cutting Arrangement}

The available production of grass dry matter and carrying capacity based on cutting arrangement in Timor Tengah Selatan District are presented in Table 4, 5,6 , and 7 . There was no significant interaction $(\mathrm{P}>0.05)$ between the location and cutting intervals for grass dry matter production available during rainy season. Location and cutting interval significantly affected grass dry matter production available during rainy season $(\mathrm{P}<0.05)$. Mollo Utara Sub District produced a significantly higher $(\mathrm{P}<0.05)$ grass dry matter than Noebeba and Amanuban Selatan Sub Districts. This difference was caused by the differences in altitude, temperature, rainfall, land type, forage type, and livestock numbers (Herawati \& Miranti, 2012) as well as the level of pasture, variation of soil moisture, grassland management, and stocking rate (Nunez et al., 2007). Grass cutting conducted in February-March with a rainfall amounted to $946.9 \mathrm{~mm}$ (BPS, 2014) caused an unbalance and decreased production of forage quantity and quality (Lambert, 2007; Hariadi, 2008). Grass dry matter production available with the cutting intervals of a month was lower as compared to that available with the 2-month 
cutting interval. This difference was due to the longer period required by the grass to rest and regrowth.

There was no significant interaction $(\mathrm{P}>0.05)$ between the location and cutting intervals for carrying capacity during rainy season. Location and cutting interval significantly affected carrying capacity $(\mathrm{P}<0.05)$. This difference was due to the differences in the altitude and cutting intervals, so that the carrying capacity in Mollo Utara Sub District was 1.29 $\pm 0.21 \mathrm{AU}$, and in Noebeba Sub District was $1.31 \pm 0.38 \mathrm{AU}$, and in Amanuban Selatan Sub District was $0.83 \pm 0.24$ AU. According to Damry (2009), the ideal carrying capacity was 2.50 AU/ ha/yr, and when the cutting interval setting was a month the carrying capacity was $1.34 \pm 0.30$ AU that was higher than $0.95 \pm 0.25 \mathrm{AU}$ when the cutting interval setting was 2 months. According to Setyanti et al. (2013), the carrying capacity is affected by the type of grass, rainfall, the type of soil, and the ability of the grass to regrThere was no significant interaction effect $(\mathrm{P}>0.05)$ between the location and cutting intervals on grass dry matter production available during dry season. Location and cutting interval significantly affected grass dry matter production available $(\mathrm{P}<0.05)$. Amanuban Selatan and Mollo Utara Sub Districts had significantly higher $(\mathrm{P}<0.05)$ grass dry matter production available as compared to Noebeba Sub District. This difference was caused by the

Table 4 . The average of grass dry matter production available $(\mathrm{kg} / \mathrm{ha} / \mathrm{yr})$ during rainy season

\begin{tabular}{ccccc}
\hline \multirow{2}{*}{ Cutting intervals } & \multicolumn{3}{c}{ Locations } & \multirow{2}{*}{ Average* $^{*}$} \\
\cline { 2 - 4 } & $\begin{array}{c}\text { Mollo Utara } \\
(1,007 \mathrm{~m} \text { asl })\end{array}$ & $\begin{array}{c}\text { Noebeba } \\
(500 \mathrm{~m} \text { asl })\end{array}$ & $\begin{array}{c}\text { Amanuban Selatan } \\
(65 \mathrm{~m} \text { asl })\end{array}$ & $252.35 \pm 57.60^{\mathrm{b}}$ \\
\hline 1 Month & $270.75 \pm 52.54$ & $298.50 \pm 90.19$ & $187.80 \pm 48.16$ & $356.78 \pm 94.88^{\mathrm{a}}$ \\
2 Month & $492.56 \pm 89.58$ & $391.32 \pm 99.30$ & $249.47 \pm 65.49$ & \\
Average $^{* *}$ & $350.16 \pm 112.30^{\mathrm{a}}$ & $344.91 \pm 65.63^{\mathrm{a}}$ & $218.64 \pm 43.61^{\mathrm{b}}$ & \\
\hline
\end{tabular}

Note: *Means in the same column with different superscripts differ significantly $(\mathrm{P}<0.05)$. ${ }^{*}$ Means in the same raw with different superscripts differ significantly $(\mathrm{P}<0.05)$. asl= above sea level.

Table 5. The average of carrying capacity (AU/ha/yr) during rainy season

\begin{tabular}{ccccc}
\hline \multirow{2}{*}{ Cutting intervals } & \multicolumn{3}{c}{ Locations } & \multirow{2}{*}{ Average* $^{*}$} \\
\cline { 2 - 4 } & $\begin{array}{c}\text { Mollo Utara } \\
(1,007 \mathrm{~m} \text { asl })\end{array}$ & $\begin{array}{c}\text { Noebeba } \\
(500 \mathrm{~m} \text { asl })\end{array}$ & $\begin{array}{c}\text { Amanuban Selatan } \\
(65 \mathrm{~m} \text { asl })\end{array}$ & $1.34 \pm 0.30^{\mathrm{a}}$ \\
\hline 1 Month & $1.43 \pm 0.28$ & $1.58 \pm 0.48$ & $1.00 \pm 0.26$ & $0.95 \pm 0.25^{\mathrm{b}}$ \\
2 Month & $1.14 \pm 0.24$ & $1.04 \pm 0.26$ & $0.66 \pm 0.17$ & \\
Average $^{* *}$ & $1.29 \pm 0.21^{\mathrm{a}}$ & $1.31 \pm 0.38^{\mathrm{a}}$ & $0.83 \pm 0.24^{\mathrm{b}}$ & \\
\hline
\end{tabular}

Note: ${ }^{*}$ Means in the same column with different superscripts differ significantly $(\mathrm{P}<0.05)$. ${ }^{* *}$ Means in the same raw with different superscripts differ significantly $(\mathrm{P}<0.05)$. asl= above sea level.

Table 6. The average of grass dry matter production available $(\mathrm{kg} / \mathrm{ha} / \mathrm{yr})$ during dry season

\begin{tabular}{lcccc}
\hline \multirow{2}{*}{ Cutting intervals } & \multicolumn{3}{c}{ Locations } & \multirow{2}{*}{ Average* $^{*}$} \\
\cline { 2 - 4 } & $\begin{array}{c}\text { Mollo Utara } \\
(1,007 \mathrm{~m} \text { asl })\end{array}$ & $\begin{array}{c}\text { Noebeba } \\
(500 \mathrm{~m} \text { asl })\end{array}$ & $\begin{array}{c}\text { Amanuban Selatan } \\
(65 \mathrm{~m} \text { asl })\end{array}$ & $189.95 \pm 29.56^{\mathrm{b}}$ \\
\hline 1 Month & $222.95 \pm 68.47$ & $181.01 \pm 49.09$ & $165.90 \pm 68.46$ & $298.19 \pm 79.29^{\mathrm{a}}$ \\
2 Month & $304.67 \pm 53.28$ & $215.86 \pm 43.28$ & $374.05 \pm 114.69$ & \\
Average $^{* *}$ & $263.81 \pm 57.78^{\mathrm{a}}$ & $198.44 \pm 24.64^{\mathrm{b}}$ & $269.98 \pm 147.18^{\mathrm{a}}$ & \\
\hline
\end{tabular}

Note: *Means in the same column with different superscripts differ significantly $(\mathrm{P}<0.05)$. ${ }^{*}$ Means in the same raw with different superscripts differ significantly $(\mathrm{P}<0.05)$. asl= above sea level.

Table 7. The average of carrying capacity (AU/ha/yr) during dry season

\begin{tabular}{ccccc}
\hline \multirow{2}{*}{ Cutting intervals } & \multicolumn{3}{c}{ Locations } & \multirow{2}{*}{ Average* $^{*}$} \\
\cline { 2 - 4 } & $\begin{array}{c}\text { Mollo Utara } \\
(1,007 \mathrm{~m} \mathrm{asl})\end{array}$ & $\begin{array}{c}\text { Noebeba } \\
(500 \mathrm{~m} \text { asl })\end{array}$ & $\begin{array}{c}\text { Amanuban Selatan } \\
(65 \mathrm{~m} \text { asl })\end{array}$ & $1.01 \pm 0.16$ \\
\hline 1 Month & $1.18 \pm 0.36$ & $0.96 \pm 0.26$ & $0.88 \pm 0.36$ & $0.79 \pm 0.21$ \\
2 Month & $0.81 \pm 0.14$ & $0.57 \pm 0.11$ & $0.99 \pm 0.30$ & $0.94 \pm 0.08$ \\
Average & $1.00 \pm 0.26$ & $0.77 \pm 0.28$ & & \\
\hline
\end{tabular}

Note: asl= above sea level. 
differences in climate, rainfall, land type, forage type, livestock numbers, and pastures pressure (Dhalika et al., 2006; Pebriansyah et al., 2012). Grass cutting conducted in June-July with rainfall amounted to $969.1 \mathrm{~mm}$ (BPS, 2014) caused an unbalance of production and reduced forage quantity and quality (Lambert, 2007; Hariadi, 2008). Grass dry-matter production available with the cutting intervals of a month was lower than that with 2-months interval. This difference was due to the longer period required by the grass to rest and regrowth.

There was no significant interaction effect $(P>0.05)$ between the location and cutting intervals on carrying capacity during dry season. Location and cutting interval did not significantly affect carrying capacity during dry season $(P>0.05)$. Carrying capacity in Mollo Utara Sub District was $1.00 \pm 0.26$ AU that was higher than that in Amanuban Selatan and Noebeba Sub Districts i.e., $0.94 \pm 0.26 \mathrm{AU}$ and $0.77 \pm 0.28 \mathrm{AU}$, respectively. According to Damry (2009), the ideal carrying capacity was 2.50 $\mathrm{AU} / \mathrm{ha} / \mathrm{yr}$. When the cutting interval setting was onemonth, the carrying capacity was $1.01 \pm 0.16$ AU that was higher than $0.79 \pm 0.21 \mathrm{AU}$ when the cutting interval setting was 2-month. This difference was affected by the type of grass, rainfall, soil type, and the ability of the grass to regrowth (Setyanti et al., 2013).

Table 8. Nutrient content of grass during rainy season with onemonth cutting interval

\begin{tabular}{lccc}
\hline & \multicolumn{3}{c}{ Locations } \\
\cline { 2 - 4 } $\begin{array}{l}\text { Nutritions } \\
\text { (\% Dry matter })\end{array}$ & $\begin{array}{c}\text { Mollo Utara } \\
(1,007 \mathrm{~m} \text { asl })\end{array}$ & $\begin{array}{c}\text { Noebeba } \\
(500 \mathrm{~m} \text { asl })\end{array}$ & $\begin{array}{c}\text { Amanuban } \\
\text { Selatan } \\
(65 \mathrm{~m} \text { asl })\end{array}$ \\
\hline Crude protein & 13.43 & 8.64 & 9.63 \\
Crude fiber & 27.63 & 26.81 & 29.49 \\
Ether extract & 1.04 & 1.18 & 0.99 \\
Nitrogen free & 46.64 & 50.02 & 51.17 \\
extract & & & \\
Neutral detergent & 80.37 & 87.21 & 84.89 \\
fiber & & & \\
Acid detergent fiber & 51.34 & 62.50 & 71.14 \\
Hemicellulosa & 29.02 & 24.71 & 13.75 \\
Cellulose & 36.21 & 47.91 & 48.60 \\
Lignin & 10.58 & 11.11 & 18.16 \\
\hline
\end{tabular}

Note: The results of laboratory analysis of Nutrition and Feed Technology-Bogor Agricultural University (2013), asl= above sea level.

\section{Grass Nutrition Production and Quality of Nutrition}

Nutrient content of grasses cut during the rainy season in Timor Tengah Selatan are presented in Table 8. The highest content of crude protein was found in the District of Mollo Utara. The difference found in nutrient content of the grass were influenced by the genetic variation of species (Hanafi et al., 2005; Orr, 2008), differences of species, varieties, growth phase, land fertility, climatic conditions, and part of the plant (Damry, 2009) as well as the composition of botanical and system of grazing that are applied. According to Alfian et al. (2012), condition of the location, age of harvesting, and nutrient content of the species affect the quality and quantity of forage production. Based on the observation, there were different species of forages in three sub districts. Forage species in Mollo Utara Sub District was dominated by P. conjugatum Berg, C. aciculatus (Retz.) Trin, and Cyperus sp. Forage species in Noebeba Sub District was dominated by H. contortus (L.) Beauv. Ex R. \& S, E. leschenaultiana (Decne.) Ohwi, while forage species in Amanuban Selatan Sub District was dominated by E. leschenaultiana (Decne.) Ohwi and H. contortus (L.) Beauv. ex R. \& S. The high diversity of species of grass in the pasture in the Sub District of Mollo Utara was probably related to a better soil fertility and species diversity of grass and forage in this sub-district as compared to Noebeba and Amanuban Selatan Sub districts (Junaidi \& Sawen, 2010).

Potential production of dry matter (DM), organic matter $(\mathrm{OM})$, crude protein $(\mathrm{CP})$, and ether extract $(\mathrm{EE})$ during the rainy season with cutting interval of a month in Timor Tengah Selatan are presented in Table 9.

The average potential production in Timor Tengah Selatan was 1,208.71 ton of DM, 145.37 ton of OM, 150.45 ton of $\mathrm{CP}$, and 26.45 ton of EE (Table 9). The highest production potential was found in Mollo Utara Sub District that located in hill with high rainfall and low temperature (Mullik \& Permana, 2009). In Amanuban Selatan Sub District, many factors affecting the production potential were location, wide harvesting age, land condition, rainfall, and nutrition content of forage (Alfian et al., 2012). The low production potential in Amanuban Selatan Sub District is related to the location near the Oetune beach that has a high temperature with a very low rainfall. Low rainfall causes the decrease in the rate of photosynthesis so that productivity decreases.

The process of photosynthesis will run well when the availability of nutrients, sunlight, water, and $\mathrm{CO}_{2}$ were fulfilled for plants (Setyanti et al., 2013). Forage

Table 9. Grass potential production of dry matter (DM), organic matter (OM), crude protein (CP), ether extract (EE) during rainy season with one-month cutting interval

\begin{tabular}{|c|c|c|c|c|c|c|c|}
\hline \multirow{2}{*}{ Locations } & \multicolumn{4}{|c|}{ Potential production (ton/ha) } & \multicolumn{3}{|c|}{ Potential production (\%) } \\
\hline & $\mathrm{DM}$ & $\mathrm{OM}$ & $\mathrm{CP}$ & $\mathrm{EE}$ & $\mathrm{OM}$ & $\mathrm{CP}$ & $\mathrm{EE}$ \\
\hline Mollo Utara (1007 m) & $1,002.56$ & 181.52 & 217.26 & 50.42 & 78.88 & 94.42 & $7: 30$ \\
\hline Noebeba (500 m) & $1,499.25$ & 145.59 & 128.22 & 18.47 & 46.96 & 41.36 & 5.95 \\
\hline Amanuban Selatan (65 m) & $1,124.34$ & 109.02 & 105.89 & 10.47 & 32.93 & 31.99 & $4: 22$ \\
\hline Average & $1,208.71$ & 145.37 & 150.45 & 26.45 & & & \\
\hline
\end{tabular}


production potential because of photosynthesis depends on the age of the plant, while the proportion of forage components changed every phase of growth (Sawen, 2012).

\section{CONCLUSION}

The grass type dominated the pasture in the Sub District of Mollo Utara, while legum type was more dominant in the pasture in the Sub Districts of Noebeba and Amanuban Selatan. Based on the real condition, grass dry matter potential production and carrying capacity were lower. One-month cutting interval in the Sub District of Mollo Utara and 2 months cutting interval in Noebeba and Amanuban Selatan Districts could increase grass dry matter potential production, carrying capacity, nutrition production, and quality of nutrition.

\section{REFERENCES}

Alfian, Y., F. I. Hermansyah, E. Handayanta, Lutojo, \& W. P. S. Suprayogi. 2012. Analysis the carrying capacity of ruminant livestock in the dry season at dry land agricultural area Semin District Gunungkidul Regency. J. Tropical Animal Husbandry. 1:33-42.

Angassa, A., A. Tolera, \& A. Belayneh. 2006. The effects of physical environment on the condition of rangelands in Borana. Trop. Grasslands. 40:33-39.

AOAC. 2005. Official Methods of Analysis of AOAC International. $18^{\text {th }}$ ed. Assoc. Off. Anal. Chem.,Arlington.

BPS. 2014. Timor Tengah Selatan dalam Angka.Badan Pusat Statistik Kabupaten Timor Tengah Selatan.

Damry. 2009. Production and nutrients composition of forages produced from a natural grassland in Lore Utara subdistrict, Poso district. J.Agroland. 16:296-300.

Dhalika, T., Mansyur, H. K. Mustafa, \& H. Supratman. 2006. Proportion of African star grass and sentro in mix pasture system on production and quality of forages. J. Ilmu Ternak. 6:163-168.

Halls, L. K., R. H. Hughes, R. L. Rummel, \& B. L. Southwel. 1964. Forage and Cattle Management in Longleaf-Slaash Pine Forest. Farmer's Bulletin, 2119. US Department of Agriculture, Washington D.C.

Hall, T. J. \& R. W. Walker. 2005. Pasture legume adaptation to six environments of the seasonally dry tropics of north Queensland. Trop. Grasslands. 39:182-196.

Hanafi, N. D., S. Umar, \& I. Bachari. 2005. The effect levels of the shade at various pasture mixtures towards the production of suitables. J. Agribisnis Peternakan. 1:100-105.

Hariadi, B. T. 2008. Carrying capacity of wallaby (Macropus agilis) at savannah of Mar, Wasur National Park Merauke District. J. Ilmu Peternakan. 3:58-63.

Herawati, T. \& Miranti. 2012. Fodder plant for strengthening terrace. J. Pastura. 1:35-38

Jones, R. J. \& R. P. Lefeuvre. 2006. Pasture production, pasture quality and their relationships with steer gains on irrigated, N-fertilised pangola grass at a range of stocking rates in the Ord Valley, Western Australia. Trop. Grasslands. 40:1-13.

Junaidi, M. \& D. Sawen. 2010. Botanical variety and carrying capacity of natural pasture at Yapen Regency. J. Ilmu Peternakan.5:92-97.

Kamlasi, Y., M. L. Mullik, \& T. O. Damidato. 2014. Pola produksi dan nutrisi rumput kume (Shorgum plumosum var. Timorense) pada lingkungan alamiahnya. J. Ilmu-Ilmu Peternakan. 24:31-40.
Lambert, G. 2007. Pasture management. Trop. Grasslands. 41:216-219.

Lowe, K. F., M. N. Callow, T. M. Bowdler, S. A. Lowe, J. A. White, \& N. Gobius. 2009. The performance of irrigated mixtures of tall fescue, ryegrass and white clover in subtropical Australia. 1. The effects of sowing mixture combinations, nitrogen and oversowing on establishment, productivity, botanical composition and persistence. Trop. Grasslands. 43:4-23.

Mannetje, L. \& K. P. Haydock. 1963. The dry weight rank method for the botanical analysis of pasture. J. Brit Grassland Soc. 18:268-275. http://dx.doi.org/10.1111/j.1365-2494.1963. tb00362.x

Manu, A. E. 2013. Produktivitas padang penggembalaan sabana Timor Barat. J. Pastura. 3:25-29.

Mullik, M. L. \& B. Permana. 2009. Improving growth rate of Bali cattle grazing native pasture in wet season by supplementing high quality forages. JITV. 14:192-199.

Njurumana, G. N. D., B. A. Victorino, \& Pratiwi. 2008. Potency of mamar development as a model of community forest in critical land rehabilitation at Timor Barat. J. Penelitian Hutan dan Konservasi Alam. 5:473-484.

Nunez, P., R. Demanet, F. Matus, \& M. L. Mora. 2007. Grazing management, ammonia and nitrous oxide emissions: a general view. J. Soil Sc. Plant Nutr. 7:61-99.

Orr, D. M. 2008. Grazing management influences the dynamics of populations of Stylosanthes hippocampoides (Oxley fine stem stylo). Trop. Grasslands. 42:193-201.

Pebriansyah, A., P. D. M. H. Karti, \& A. T. Permana. 2012. Effect of drought stress and addition of Arbuscula Mycorrhizal Fungi (AMF) on growth and productivity of tropical grasses (Chloris gayana, Paspalum dilatatum, and Paspalum notatum). J. Pastura. 2:41-48.

Quattrocchi, U. 2006. CRC World Dictionary of Grasses: Common Names, Scientific Names, Eponyms, Synonyms, and Etymology. Taylor \& Francis Group, Boca Raton. http:// dx.doi.org/10.1201/9781420003222

Rusdin., M. Ismail, Mustaring, S. Purwaningsih, A. Andriana, \& S. U. Dewi. 2009. Studi potensi kawasan Lore Tengah untuk pengembangan sapi potong. Media Litbang Sulteng. 2:94-103.

Salendu, A. H. S. \& F. H. Elly. 2012. Land utilization under the coconut tree to forage for cattle in North Sulawesi. J. Pastura. 2:21-25.

Sawen, D. 2012. Growth of Pennisetum purpureum and Panicum maximumbase on intensity of solar radiation. J. Ilmu Ternak dan Tanaman. 2:17-20.

Setyanti, Y. H., S. Anwar, \& W. Slamet. 2013. Photosynthesis characteristic and phospor uptake of alfalfa (Medicago sati$v a)$ in different defoliation intensity and nitrogen fertilizer. J. Anim. Agric. 2:86-96.

Som, K. R. 1996. Practical Sampling Techniques. $2^{\text {th }}$ ed. Revised and Expanded. Marcel Dekker Inc., New York.

Stone, B. C. 1983. A Guide to Collecting Pandanaceae (Pandanus, Freycinetia, Sararanga). Ann. Missouri Bot. Gard. 70:137-140. http://dx.doi.org/10.2307/2399011

Steel, R. G. D. \& J. H. Torrie. 1993. Prinsip dan Prosedur Statistika (Pendekatan Biometrik). Sumantri B, penerjemah. Gramedia Pustaka Utama. Terjemahan dari: The Principle and Prosedure of Statistics. Jakarta.

Susetyo, S. 1980. PadangPenggembalaan. Bogor Agricultural University. Bogor.

Tillman, A. D., H. Hartadi, S. Reksohadiprodjo, S. Prawirokusomo, \& S. Lebdosoekojo. 1983. Ilmu Makanan Ternak Dasar. Gadjah Mada University. Yogyakarta.

Tola, T., P. T. Balla, \& B. Ibrahim. 2007. Analisis daya dukung dan produktivitas lahan tanaman pangan di Kecamatan Batang Kabupaten Jeneponto Sulawesi Selatan. J. Ilmu Tanah dan Lingkungan. 7:13-22. 